\title{
Evaluation of the pair-culture effect in Ophryotrocha puerilis (Polychaeta: Dorvilleidae). II. Conditions for the moult of the upper jaw
}

\author{
B. Kegel* \& H.-D. Pfannenstiel \\ Institut für Allgemeine Zoologie, Freie Universität Berlin; Königin-Luise-Str. 1-3, \\ D-1000 Berlin 33, Federal Republic of Germany
}

\begin{abstract}
The conditions for moult of the upper jaw of Ophryotrocha puerilis were determined in isolated individuals and in groups of various sizes. The frequency of formation of the complicated upper jaw in both isolated individuals and in groups varies to a considerable extent. Although formation of the upper jaw and sex reversal normally are associated processes, the relationship of these two processes is not very well understood. Histological investigations at the light microscopic level demonstrate that the dental apparatus is an elaboration of the ectodermal stomodaeum which is considered to be a highly specialized part of the cuticle in the pharyngeal region of the gut.
\end{abstract}

\section{INTRODUCTION}

The existence of jaws in the pharyngeal region of the foregut is a characteristic feature of eunicid polychaetes including the family Dorvilleidae. These structures are modified parts of the cuticle which are thick and sclerous. They represent elaborations of the ectodermal stomodaeum. The dental apparatus in the dorvilleid genus Ophryotrocha is composed of two rods (mandible) and two forceps-like maxillae with a number of maxillary plates connected to the maxillae (Fig. 4a). The maxillae and the plates are moulted from time to time. In at least two species the newly moulted jaw always is of the same appearance as the old one (O. gracilis; Dohle, 1967; O. natans; Pfannenstiel, 1975). This type of jaw is called p-jaw (primitive jaw). In a number of species a second type of upper jaw may replace the old one. This so-called k-jaw (from the German term "kompliziert" - complicated) shows a pair of big claws instead of the small forceps-like maxillae of the p-jaw. The maxillary plates are of the same shape in both p-jaw and k-jaw (Fig. 4a). The appearance of the k-jaw depends upon certain conditions. In $O$. labronica, the $\mathrm{k}$-jaw normally appears at a sex specific number of setigerous segments (ss) (Pfannenstiel, 1976). In the protandric O. puerilis, the k-jaw is formed when females switch back to males (Düsing, 1961; Müller, 1962; Pfannenstiel, 1977; see also Kegel \& Pfannenstiel, 1983 for further literature concerning the pair-culture effect). The $\mathrm{k}$-jaw represents the final maxillary apparatus and is never moulted again. The func-

- Present address: Institut für Biologie der Technischen Universität Berlin; Franklinstr. 28/29, D-1000 Berlin 10, Federal Republic of Germany 
tional relevance of the different types of upper jaws and the significance of the sexual differentiation for the moult of the primitive type jaw (p-jaw) to the k-jaw are not yet understood. The present study provides some quantitative aspects of $\mathrm{k}$-jaw formation in isolated individuals, in pairs, and in larger groups of worms. Also, the development of the k-jaw is described as investigated at the light microscope level.

\section{MATERIALS AND METHODS}

The origin of our laboratory cultures of Ophryotrocha puerilis puerilis has been reported recently (Kegel \& Pfannenstiel, 1983). The culture methods have been described elsewhere (Pfannenstiel, 1973). In the experimental animals, sex, number of setigerous segments (ss), and jaw formation were recorded at frequent intervals without anaesthetizing the specimens. For light microscopy, the animals were fixed in sea waterBouin, dehydrated in a graded series of ethanol and then embedded in Paraplast. The $5 \mu \mathrm{m}$ sections were stained in Azan and examined with a Zeiss photomicroscope III.

\section{RESULTS}

\section{Frequency of k-jaw formation.}

The spontaneous appearance of k-jaws in isolated specimens and the frequency of $\mathrm{k}$-jaw formation in pairs and groups of formerly isolated individuals have been recorded. As reported in a previous paper (Kegel \& Pfannenstiel, 1983), 50 to $60 \%$ of the newly formed males in various pair-culture experiments have been found to show concomitant $\mathrm{k}$-jaw formation. In groups of fifty animals $\left(\mathrm{L}_{1}-\mathrm{L}_{3}\right.$, Fig. 1), up to $60 \%$ developed a k-jaw within ten days. The percentage of $\mathrm{k}$-jaws increased to slightly more than $80 \%\left(\mathrm{~L}_{2}\right.$ and $\mathrm{L}_{3}$, Fig. 1) within the observation period. Since k-jaws are the definitive upper jaws which are never moulted again, falling percentages in the graphs of Figure 1 are due to losses of animals which already exhibited $\mathrm{k}$-jaws. It is not clear whether the remaining animals without $\mathrm{k}$-jaws performed sex reversals during the observation period or not. As a matter of fact, there were some specimens found to be males and to have the $p$-jaw at the end of the observation period. It is not possible to follow the fate of a single individual in larger groups. A certain percentage of $\mathrm{k}$-jaw formation in these three experimental groups (Fig. 1) paralleled the sex reversals to the male phase. The degree and nature of this interdependence could not be determined by our experimental design. Essentially the same results have been obtained in groups consisting of 25 formerly isolated females.

In isolated females up to $50 \%$ of the animals replaced their $\mathrm{p}$-jaw by the definitive k-jaw without social interactions. In earlier experiments (Müller, 1962; Pfannenstiel, 1977) $\mathrm{k}$-jaw formation was linked with sex reversal and restricted to the sex reverting partner of a pair. The striking difference to the present results may be due to a different geographical origin of the material employed in these older studies.

In order to determine whether environmental conditions play a role during spontaneously occurring $\mathrm{k}$-jaw formation, three groups of isolated females $(\mathrm{n}=20)$ were kept under different conditions. The first group was a control group. These 20 females were fed spinach and their sea water was changed frequently. The second group was starved 


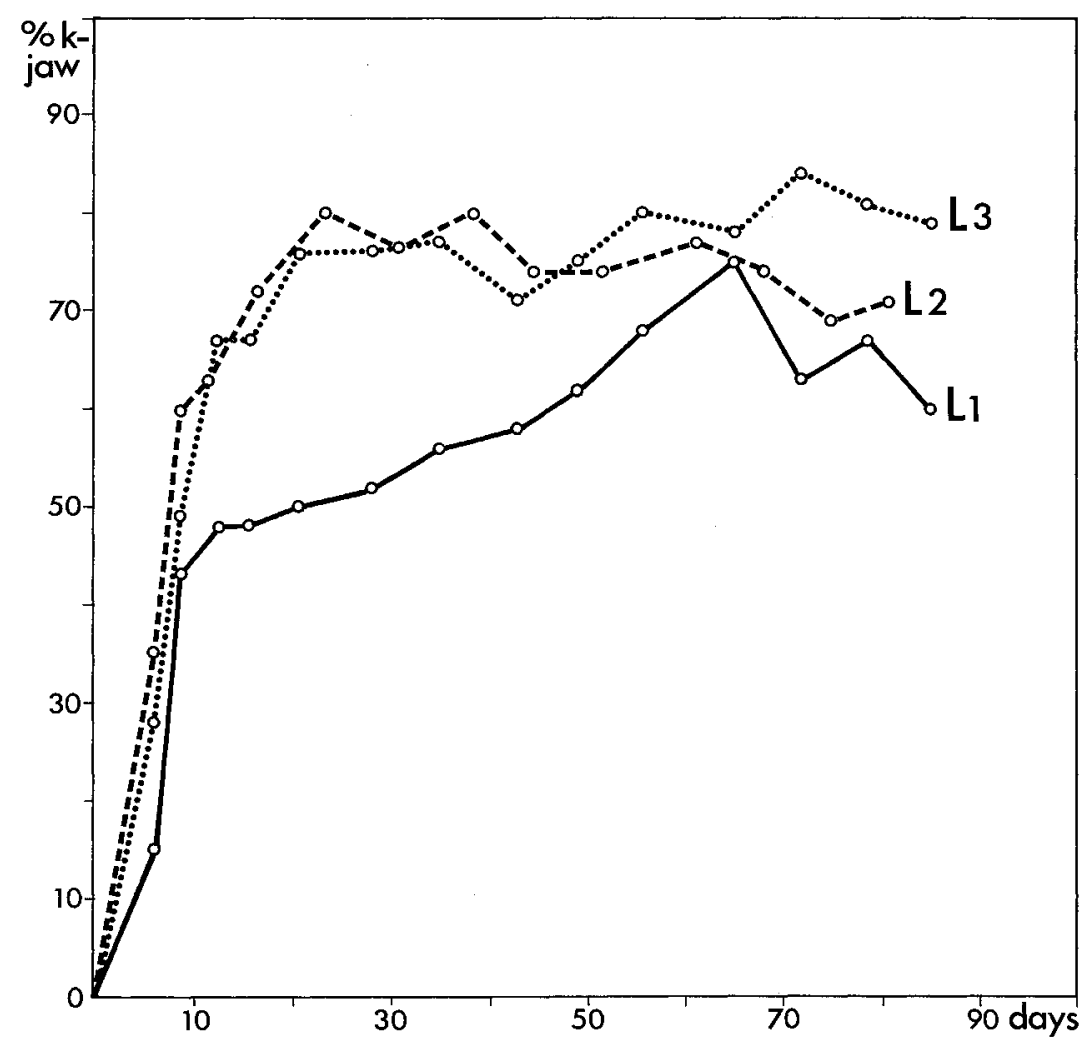

Fig. 1. Ophryotrocha puerilis; percentages of $\mathrm{k}$-jaw formation in three groups of fifty formerly isolated females $\left(L_{1}, L_{2}, L_{3}\right)$ during an observation period of ninety days

but the sea water was changed normally. The third group was fed spinach without any changes of sea water and without cleaning the culture bowls. This results in very bad water quality and heavy microbial contamination after a few weeks. After six weeks $50 \%$ of the animals, both in the control group and in the starving group, had developed a $\mathrm{k}$-jaw. In the group which suffered from bad water quality only $30 \% \mathrm{k}$-jaw formation was found.

\section{Moult cycle of the upper jaw}

Figure 2 depicts the moult cycles of an individual isolated at a length of 3 ss. The growing number of ss and the age of an individual are positively related to the length of the moult cycle. The corresponding data of a number of isolated individuals (Fig. 3, full circles) confirm this finding, although the length of the moult cycle is subject to great variations in older and longer animals with more ss. The specimen in Figure 2 was combined with another female four days after its fifth moult. Ten days later this individual performed the final moult and a k-jaw was formed. The length of the final 


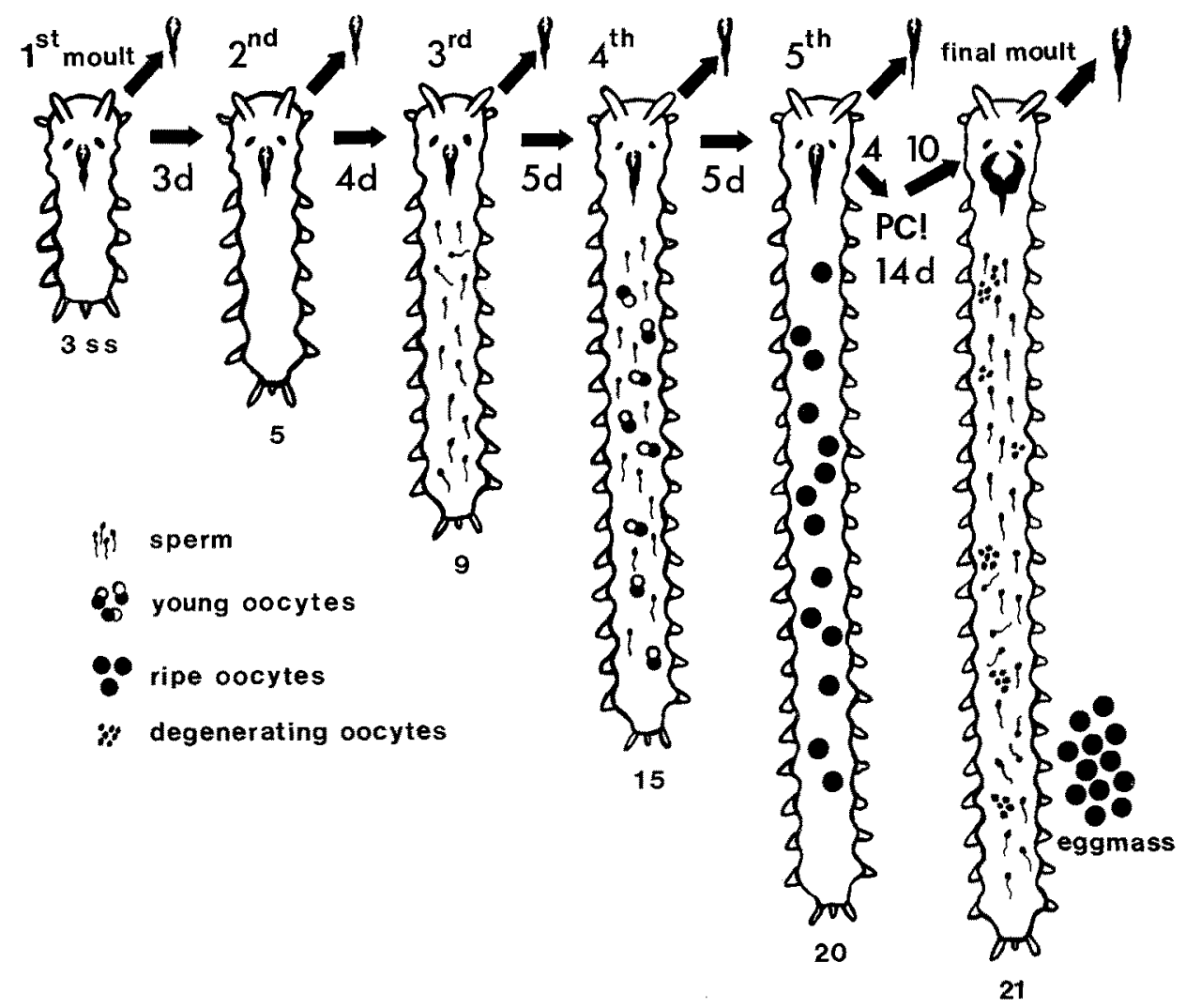

Fig. 2. Ophryotrocha puerilis; moult cycle of the upper jaw in an isolated individual; the length of each moult cycle and the number of setigerous segments at which the moult occurred are given; the individual switched from male to female after the $4^{\text {th }}$ moult; another female was added four days after the $5^{\text {th }}$ moult $(\mathrm{PC})$; ten days later the final moult and sex reversal took place

moult cycle of this individual gave the impression that the formation of the $k$-jaw was somewhat delayed with respect to the formation of another $\mathrm{p}$-jaw which would have taken place in isolation. The open circles in Figure 3 give the mean lengths of final moult cycles in relation to the number of ss at which the last moult to the p-jaw has been recorded. These data also suggest that the formation of the k-jaw is delayed with respect to the formation of another $\mathrm{p}$-jaw which presumably would have taken place in specimens when still being isolated. The full circles in Figure 3 do not only comprise final moult cycles of isolated individuals but also those of individuals which were combined with another female. The time at which the partners were combined is not shown in Figure 3.

\section{Histology of $\mathrm{k}$-jaw development}

The replacement of one $\mathrm{p}$-jaw by another $\mathrm{p}$-jaw has been found to take 36 hours at least $\left(19 \pm 1{ }^{\circ} \mathrm{C}\right)$. The development of a k-jaw took even longer (40 hours). Müller (1962) 


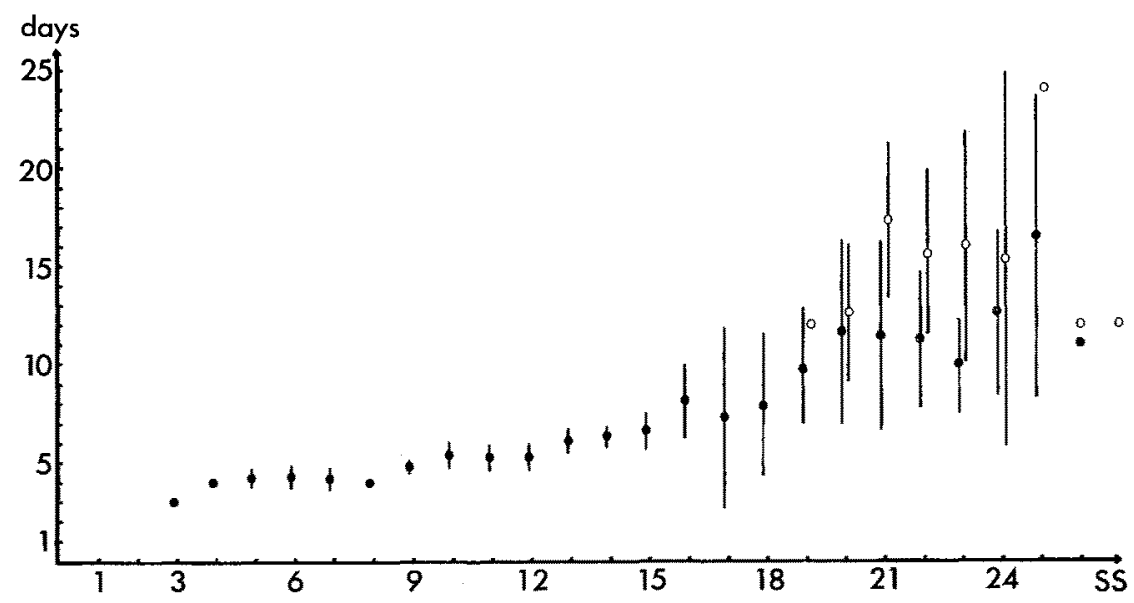

Fig. 3. Ophryotrocha puerilis; moult cycles of the upper jaw; full circles: lengths of moult cycles from p-jaw to another p-jaw in relation to number of setigerous segments (ss) at which the preceding moult took place; open circles: lengths of final moult cycles in relation to number of ss at which the last normal moult took place; data comprise only partner-induced $k$-jaw formations; $\mathrm{n}=25 ;$ means including standard deviations are given

reported much shorter times $\left(22-32\right.$ hours; $\left.20-23^{\circ} \mathrm{C}\right)$. The new dental apparatus develops while the old one is still in use. Once the new jaw is fully differentiated, the old one is either swallowed or shed via the mouth. Animals with two rows of dental plates on either side of the pharynx and specimens with one dental apparatus in the gut are frequently found in the cultures.

The upper jaws are formed in epithelial sac-like structures which are situated ventrolateral to the upper jaw present at that moment (Fig. 4c, d). In the region where the big claws of the k-jaw are formed, the sacs show a very regular arrangement of the nuclei of the epithelial cells (Fig. 4c, d). During the intermoult phase (Fig. 4b) the "sacs" do not show a lumen. Prior to the secretion of the new jaw the epithelial cells move apart thus creating the lumen of the sac. At the moment of jaw formation this cavity is filled with a noncellular blue staining secretion product which is believed to represent material of the cuticle which has not yet undergone hardening. At the sites of secretion of the small maxillary plates in front of the big claws (Fig. 4e) and at the region where the basal stalk joining the two claws is secreted (Fig. 4f) the arrangement of the foregut epithelium and the localization of nuclei within the cells is much more irregular. This arrangement possibly reflects the complex structure of the dental plates secreted there. At the lateralmost parts of the sacs much less nuclei can be found. Perhaps there is only one nucleus located here (Fig. 4d). The development of the big forceps starts at that region of the foregut epithelium. The secretion and hardening of all the structures of the $\mathrm{k}$-jaw start on either side of the median line and then gradually proceed to more lateral parts (Fig. 4a). In the anteroposterior axis the tips of the small maxillary plates and the tips of the big claws appear first (Fig. 4a). These structures seem to appear independently on either side. The connecting elements between the various parts of the upper jaw are formed later on. 

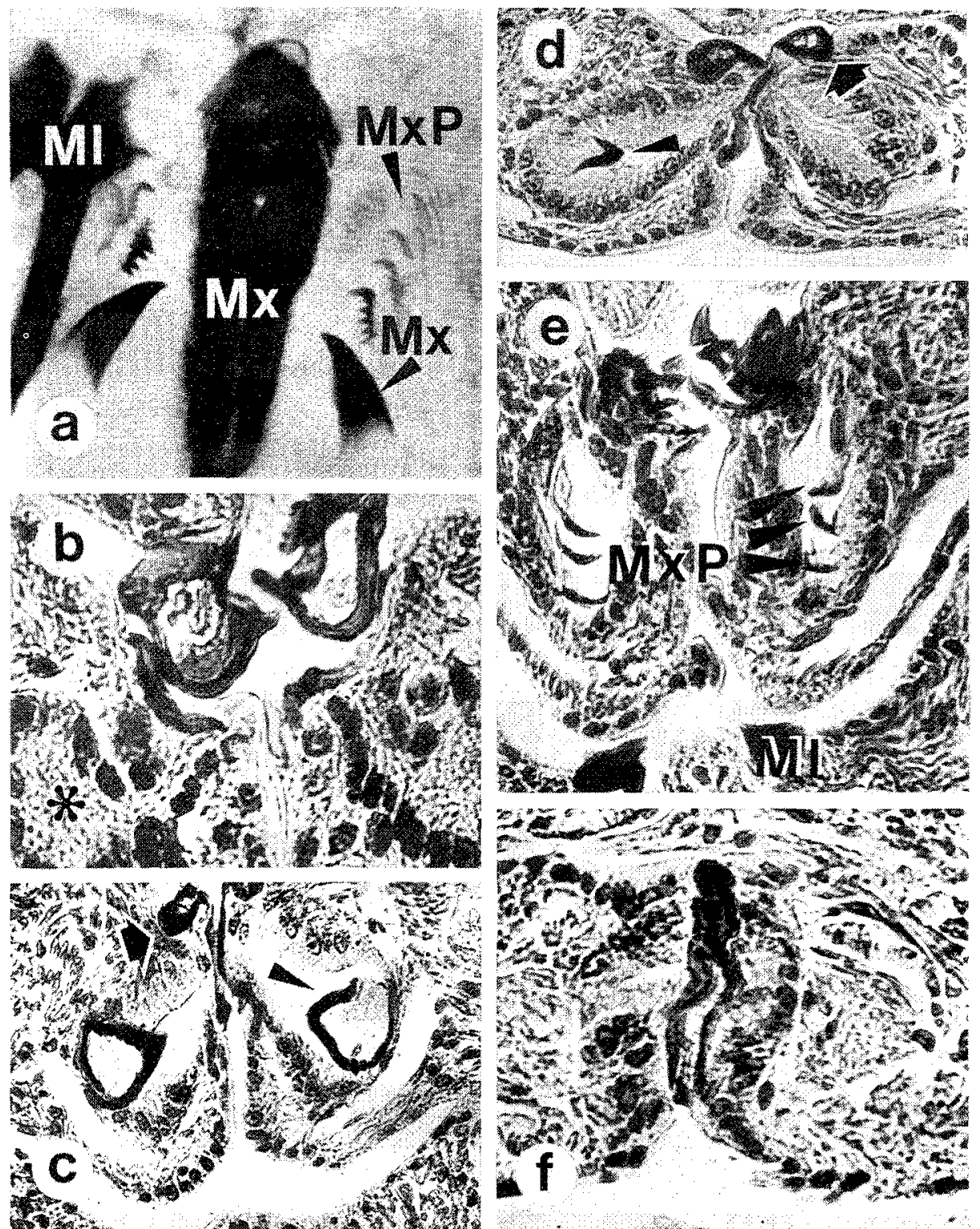

Fig, 4. Ophryotrocha puerilis; histology of $\mathrm{k}$-jaw formation; (a) newly forming maxillae (Mx with arrowhead) and maxillary plates; $\mathrm{Mx}$, old maxilla, $\mathrm{Ml}$, mandible, $\times 210$; (b) dental apparatus in cross section, note absence of lumen (") in epithelial sac, $\times 700$; (c) old maxillae (arrow) with newly forming maxillae (arrowhead) in epithelial $\mathrm{sac}_{*} \times 240_{;}$(d) newly forming maxillae (arrowhead) in epithelial sac sectioned posterior to $c$, arrow indicates old maxillae; note regular arrangement of nuclei in epithelial sac; note also that only few nuclei are present at the lateral margins of the sacs, $\times 290$; (e) newly forming maxillary plates (MxP), mandible (Ml) visible, note complex structure of this part of the epithelial sac, $\times 320$; (f) region of the stalk of the old maxillae note that formation of a new stalk has not yet been started, $\times 380$ 


\section{DISCUSSION}

A number of phenomena of sexual development in Ophryotrocha puerilis vary to a considerable extent according to the geographical origin or the genetic state of the strain used. The number of ss at which the Mediterranean subspecies $O$. p. puerilis switch from the male to the female phase was determined by Bacci \& Voria (1970). Also, the number of ss at which the first gametes appear in the coelomic fluid is subject to great variations (Åkesson, 1983). Kegel \& Pfannenstiel (1983) showed that not all pairs formed out of formerly isolated females of $O$. $p$. puerilis performed the pair-culture effect. The present results demonstrate that the frequency and the time of $\mathrm{k}$-jaw development also vary to a great extent. Berruti (1980) found a lower rate of $\mathrm{k}$-jaw formation in starved paircultures. According to her interpretation this was due to a general injuring influence of starvation. In an earlier work (Berruti, 1976), she described a genetic component influencing the $\mathrm{k}$-jaw percentages in pair-cultures, with percentages ranging from $23 \%$ to $60 \%$ in genetically different strains. Berruti (1980) also described the spontaneous formation of k-jaws in isolated females. Both findings are confirmed by the present results. Although the present authors did not carry out genetic experiments, they also attribute the different percentages found for $\mathrm{k}$-jaw formation to genetic influences rather than to modifying environmental conditions.

Postembryonic development in arthropods normally includes a series of larval moults and one imaginal moult in insects, at least. Müller (1962) pointed out that the successive moults of the upper jaw in $O$. puerilis resemble the postembryonic moults in insects. The larval moults are represented by the replacement of one p-jaw by another; the moult to the $\mathrm{k}$-jaw would resemble an imaginal moult. One implication of this idea would be that the lack of a k-jaw (as in $O$. gracilis, for example) may express a high degree of neoteny. It is interesting to note that the interstitial species $O$. gracilis which, on other grounds, is believed to show highly neotenic characters does not develop the complicated jaw during its life cycle (Dohle, 1967; Westheide, 1983).

The histological findings at the light microscopic level do not allow a comparison of $\mathrm{k}$-jaw formation with the formation of setae in Nereis vexillosa described by O'Clair \& Cloney (1974) at the electronmicroscopic level. However, it is a well known fact of polychaete reproduction that certain species develop a new bristle pattern during sexual maturation; for example, in nereids, swimming setae replace normal setae during epitokous metamorphosis. The histological findings would deserve reinvestigation at the ultrastructural level.

The dental apparatus is a highly specialized part of the cuticle of the foregut. The system controlling the moult of this structure must operate in a different way than it operates in insects since only a certain part of the whole structure (the upper jaw) is renewed from time to time. Also, ecdysteroids added to the culture medium do not influence the moult cycle (Pfannenstiel, unpublished data).

Acknowledgement. This work was supported by FPS "Adaptive Dynamik in Struktur und Leistung tierischer Organe", FU Berlin. 


\section{LITERATURE CITED}

Åkesson, B., 1983. Speciation in the genus Ophryotrocha (Polychaeta, Dorvilleidae). - Fortschr. Zool. 29, (In press).

Bacci, G. \& Voria, P., 1970. The influence of temperature upon the change from the male to the female phase in Ophryotrocha puerilis puerilis, a polychaete worm. - Experientia 26, 1273.

Berruti, G., 1976. Factors affecting the appearance of the definitive upper jaw in Ophryotrocha puerilis (Annelida Polychaeta). - Pubbl. Staz. zool. Napoli 40, 365-371.

Berruti, G., 1980. The effect of starvation on the appearance of the definitive upper jaw in Ophryotrocha puerilis (Annelida Polychaeta). - Boll. Zool. 47, 71-74.

Dohle, W., 1967. Zur Morphologie und Lebensweise von Ophryotrocha gracilis Huth 1934 (Polychaeta, Eunicidae). - Kieler Meeresforsch. 23, 68-74.

Düsing, H., 1961. Die Umwandlung des Kauapparates in Abhängigkeit vom sexuellen Zustand bei Ophryotrocha puerilis Claparède und Mecznikow. - Naturwissenschaften 48, 532-533.

Kegel, B. \& Pfannenstiel, H.-D., 1983. Evaluation of the pair-culture effect in Ophryotrocha puerilis (Polychaeta: Dorvilleidae). I. Pair-culture effect and sex ratio. - Helgoländer Meeresunters. 36, 205-213.

Müller, H., 1962. Uber die Sexualität des Polychaeten Ophryotrocha puerilis, ihre Determination und ihren Einfluß auf Drüsentätigkeit und Kauapparatentwicklung. - Z. Morph. Ökol. Tiere 52, $1-32$.

O'Clair, R. M. \& Cloney, R. A., 1974. Patterns of morphogenesis mediated by dynamic microvilli: Chaetogenesis in Nereis vexillosa. - Cell Tissue Res, 151, 141-157.

Pfannenstiel, H.-D., 1973. Der Meeresborstenwurm Ophryotrocha puerilis. Ein ideales Labortier. Mikrokosmos 62, 97-100.

Pfannenstiel, H.-D., 1975. Ophryotrocha natans n. sp. (Polychaeta, Dorvilleidae): Ein Simultanzwitter mit acht männlichen Segmenten aus dem Golf von Aqaba. - Zool. Anz. 195, 1-7.

Pfannenstiel, H.-D., 1976. Ist der Polychaet Ophryotrocha labronica ein proterandrischer Hermaphrodit? - Mar. Biol. 38, 169-178.

Pfannenstiel, H.-D., 1977. Experimental analysis of the "Paarkultureffekt" in the protandric polychaete, Ophryotrocha puerilis Clap. Mecz. - J. exp. mar. Biol. Ecol. 28, 31-40.

Westheide, W., 1983. The concept of reproduction in polychaetes with small body size: Adaptations in interstitial species. - Fortschr. Zool. 29, (In press). 